\title{
Risk Factors for Human T Cell Lymphotropic Virus Type I among Injecting Drug Users in Northeast Brazil: Possibly Greater Efficiency of Male to Female Transmission
}

\author{
Inês Dourado/ ${ }^{+}$, Tarcísio Andrade*, Catherine L Carpenter**, \\ Bernardo Galvão-Castro***
}

Instituto de Saúde Coletiva Universidade Federal da Bahia, Rua Padre Feijó 29, 4o andar, 40110-170 Salvador, BA, Brasil *Centro de Estudos e Terapia do Abuso de Drogas, UFBA, Salvador, BA, Brasil **Department of

Preventive Medicine, USC School of Medicine, Los Angeles, CA, USA ***Centro de Pesquisas Gonçalo

Moniz-Fiocruz, Salvador, BA, Brasil

It was observed in the city of Salvador, State of Bahia, the highest seroprevalence of human T cell lymphotropic virus type 1 (HTLV-I) infection in Brazil as demonstrated by national wide blood bank surveys. In this paper, we report results of an investigation of drug use and sexual behavior associated with HTLV-I infection among male and female injecting drug users (IDUs) in Salvador. A cross sectional study was conducted in the Historical District of Salvador from 1994-1996 (Projeto Brasil-Salvador) and 216 asymptomatic IDUs were selected using the snowball contact technique. Blood samples were collected for serological assays. Sera were screened for human immunodeficiency virus (HIV-1/2) and HTLV-I/II antibodies by ELISA and confirmed by Western blot. The overall prevalence of HTLV-I/ II was $35.2 \%$ (76/216). The seroprevalence of HTLV-I, HTLV-II and HIV-1 was for males $22 \%, 11.3 \%$ and $44.1 \%$ and for females $46.2 \%, 10.3 \%$ and $74.4 \%$ respectively. HTLV-I was identified in $72.4 \%$ of HTLV positive IDUs. Variables which were significantly associated with HTLV-I infection among males included needle sharing practices, duration of injecting drug use, HIV-1 seropositivity and syphilis. Among women, duration of injecting drug use and syphilis were strongly associated with HTLV-I infection. Multivariate analysis did not change the direction of these associations. Sexual intercourse might play a more important role in HTLV-I infection among women than in men.

Key words: human T cell lymphotropic virus type I/II (HTLV-I/II) - human immunodeficiency virus type 1 (HIV-1) - injecting drug use - snowball sampling - Bahia - Brazil

Human T-lymphotropic viruses (HTLV-I/II) and human immunodeficiency virus (HIV) were identified during the years 1979-1985 (Poiesz et al. 1980). HTLV-I and most likely HTLV-II can be transmitted through sexual contact, blood transfusion, sharing of injecting equipment, and from mother to child primarily through breast feeding (HTLV European Research Network 1996). Individuals infected with HTLV-I develop antibodies to the virus and become lifelong carriers. In addition, HTLV-I is associated with multiple pathologies such as adult T-cell leukemia and lymphomas,

\footnotetext{
This study was supported by grants from the PNUD/ National Coordination of STD and Aids/Brazilian Ministry of Health and the Brazilian National Research Council (CNPq) grant no. 520605/95-0.

${ }^{+}$Corresponding author. Fax: +55-71-237.5856. Email: maines@ufba.br

Received 24 June 1998

Accepted 3 November 1998
}

HTLV-I associated myelopathy or tropical spastic paraparesis, arthrits and uveites (Poiesz et al. 1981). However, there is no clear evidence until now of diseases associated with HTLV-II (CDC 1990, Hesran et al. 1994).

It is well known that injecting drug use (IDU) is an important risk factor for infection with known human retroviruses. Approximately 80 countries have documented HIV infection associated with the use of drug injection and 40 other countries have reported patterns of injecting drug behavior (Stimson 1995, Des Jarlais et al. 1996). HTLV-I/II were first recognized among IDUs in 1984 (Tedder et al. 1984). Reported seroprevalence rates of HTLV-I/II among this group range from as low as $0.4 \%$ to $53 \%$ in the United States. In Europe, a recent review article on the epidemiology of HTLV-I reported a wide variation across selected groups and higher rates up to $18 \%$ among IDUs (Taylor 1996). Differences in study design, and in the testing algorithms are possible explanations for the wide rate variation (Lee et al. 1989, 1990, Khabbaz et al. 1990, Feigal 1991). In the Unites States and Europe, HTLV-II represents 
the majority of HTLV infections among IDUs (Briggs et al. 1995).

Seroprevalence studies in Latin America have identified important geographic areas of HTLV transmission. The reported prevalence in a study with sample from the general population in Venezuela was 6.8\% (Merino et al. 1984). In Chile, of 954 samples from blood donors, $7(0.73 \%)$ were confirmed positive for HTLV-I/II (Vasquez et al. 1991). In the Amazon region, HTLV-II has been observed to be endemic among indigenous population of Brazil, particularly between the Kayapo indians with reported infection rate of $32.3 \%$ (Ishak et al. 1995).

HTLV-I infection and its associated pathologies have been described by many investigators in Brazil (Pombo de Oliveira et al. 1990, MorenoCarvalho et al. 1992, Moreira et al. 1993, Gabbai et al. 1993). A national survey with samples from blood banks reported the highest rate of $1.35 \%$ in Salvador, the capital of the State of Bahia, a city located in the Northeast region (Ferreira Jr et al. 1994, Galvão-Castro et al. 1997). Furthermore, other studies demonstrated the presence of these infections among selected groups in Brazil (Araujo et al. 1994, de Carvalho et al. 1996, Bellei et al. 1996). A seroprevalence study of retrovirus infection conducted in Salvador among IDUs, demonstrated high rates of HIV-1 (49.5\%), HTLV-I (25.5\%) and HTLV-II (8.8\%) (Andrade et al. 1998).

In this paper, we report results of an investigation of drug use and sexual behavior associated with HTLV-I infection among male and female IDUs in Salvador.

\section{MATERIALS AND METHODS}

Study population - This is a cross sectional study conducted in the colonial district of Salvador, between August 1994 and September 1996. This investigation is part of a multicenter HIV seroprevalence and behavioral study among IDUs in five Brazilian cities (Projeto Brasil-Salvador).

Salvador, the capital of the State of Bahia, is a city with approximately 2.5 million inhabitants. Its population, is roughly $80 \%$ black or racially mixed. The colonial district known as Pelourinho, is located in the Historical Center of Salvador, with approximately 20,000 inhabitants of whom $30 \%$ were below 14 years old at the time of the study. The area is now being renovated after years of architectural and social deterioration. Despite Pelourinho being an important cultural center, especially for Afro-brazilian culture, it is also surrounded by areas of marginality, prostitution, drug use and drug traffic.

The study group was identified among individuals who reside or frequent the Historical District using snowball sampling technique. The snowball technique provides a study sample based on referrals made by individuals who shared or know others who have the characteristics to be considered in the investigation (Biernack \& Walford 1981, Lopes et al. 1996). Therefore, drug dealers and drug users were contacted in the streets of Pelourinho by trained research assistants, and were invited to act as mediators between potential participants and investigators. The majority $(70 \%)$ of the study group were reached on the streets. Thirty percent were brought to the Drug Abuse Center by other IDUs to participate in the study. None of them were in drug treatment.

Eligibility criteria for the study participation included reported drug injection in the last six months and age 15 years or older. The participants were interviewed by trained research assistants who looked for "tracks" and/or broken veins in order to confirm the IDU status of the candidate. The interviewer explained the objectives of the study, clarified any doubts and asked for their signature on the consent form. The questionnaires were adapted from the World Health Organization Multicity IDU Study (WHO 1993). Data on demographics, sexual behavior, attitudes and drug use practices were obtained and $10 \mathrm{ml}$ of blood collected for serological assays.

Laboratory methods - Sera were screened for HIV-1/2 and HTLV-I/II antibodies by ELISA [Abbott HIV-1/2, 3rd generation Plus EIA, Delkenheim, Germany and HTLV-I $\left(\mathrm{rp}_{21 \mathrm{e}}\right.$ enhanced), EIA, Cambridge Biotech Corporation, Worcester, MA, USA respectively] and confirmed by Western blot [HIV-1 Cambridge Biotech Corporation, Worcester, MA, USA and HTLV Blot 2.4 Genelabs Diagnostics (GLD), Science Park Drive, Singapore respectively]. The GLD HTLV Blot 2.4 also discriminates the seroreactivity to HTLV-I and HTLV-II and consequentely differentiates the type of infection. Evidence for the presence of Treponema pallidum infection was initially evaluated by serum reactivity to non-treponemal cardiolipin antigen (VDRL Behring, Marburg, Germany). VDRL positive samples were further tested by $T$. pallidum indirect immunofluorescence (FTA, Behring, Marburg, Germany).

Data analysis - Frequency distributions were determined for each variable including mean, median and standard deviations for continuous variables. Crude odds ratios (OR) and $95 \%$ confidence intervals (CI) that measured the association of selected variables and HTLV-I infection were calculated from 2x2 tables (Fleiss 1981). Multiple logistic regression models computed adjusted estimates of potential risk behavior to HTLV-I infec- 
tion. The statistical package (SAS 1995) was used to perform the different steps of the analysis.

\section{RESULTS}

Eighty two percent (177) of the study sample were males and $18 \%$ (39) were females. They reported injecting mainly cocaine. The seroprevalence of HTLV-I, HTLV-II and HIV-1 was for males $22 \%, 11.3 \%$ and $44.1 \%$ and for females $46.2 \%, 10.3 \%$ and $74.4 \%$ respectively. HTLV-I was detected in the majority $(72.4 \%)$ of HTLV positive IDUs. Further descriptive data analysis was reported elsewhere (Dourado et al. 1998). Briefly, the mean age at enrollment was 24.6 years and 27.4 years for males and females respectively and the mean age at first intravenous drug use was 16 years for both. The median duration of intravenous drug use was six years for males and eight years for females. Most of the study group were low income IDUs with one to two years of education and an illegal source of income such as robbery and/or drug traffic.

Table I presents univariate analysis for the association of HTLV-I infection with behavior variables, HIV infection and syphilis. For males, HTLV-I was associated with needle sharing practices (OR, 7.94; 95\% CI, 1.32-47.6), duration of injecting drug use (OR, 3.30; 95\% CI, 1.60-6.80), no reference to vaginal sex in the last month (OR; 2.52; 95\% CI, 1.23-5.18) and syphilis (OR, 5.68; 95\% CI, 2.61-12.34). HTLV-I infection was highly associated with HIV-1 infection (OR, 7.52; 95\% CI, 3.42-16.39). The OR for number of people that shared needles with in the last week was 1.44 but the $95 \%$ confidence intervals included the null value. Men reporting sex with another men ever in their lifetime (72/105) was not associated with HTLV-I infection (data not shown). Among women, HTLV-I was associated only with duration of injecting drug use (OR, 6.58; 95\% CI, 1.5827.78) and syphilis (OR, 4.00; 95\% CI, 1.0016.39). The OR for number of people that shared needles with in the last week, vaginal sex in the last month and HIV-1 infection was in the direction of a positive association with HTLV-I infection ( $\mathrm{OR}=1.29 ; \mathrm{OR}=1.56 ; \mathrm{OR}=2.50$ respectively), but the $95 \%$ confidence intervals were wide and imprecise.

A significant linear trend of HTLV-I infection was demonstrated for increasing duration of injecting drug use for both males and females (Figure).

Table II shows multiple logistic regression model results for males and females. Regarding women, duration of injecting drug use remained a

TABLE I

Univariate analysis for HTLV-I ${ }^{a}$ among males and females IDUs ${ }^{b}$. Projeto Brasil-Salvador, Bahia, 1994-1996

\begin{tabular}{|c|c|c|c|c|c|c|}
\hline \multirow[t]{2}{*}{ Variable } & \multicolumn{3}{|c|}{ Males } & \multicolumn{3}{|c|}{ Females } \\
\hline & $\%$ pos. & $\mathrm{OR}^{c}$ & $95 \% \mathrm{CI}^{d}$ & $\%$ pos. & OR & $95 \% \mathrm{CI}$ \\
\hline \multicolumn{7}{|l|}{ Age of 1st drug use } \\
\hline $7-14$ & 27.2 & 1.50 & $0.72-3.13$ & 57.1 & 2.22 & $0.56-8.54$ \\
\hline $15-40$ & 19.8 & & & 37.5 & & \\
\hline \multicolumn{7}{|l|}{ Needle-sharing } \\
\hline Yes & 25.6 & 7.94 & $1.32-47.6$ & 56.3 & 1.72 & $0.28-10.64$ \\
\hline No & 4.17 & & & 42.9 & & \\
\hline \multicolumn{7}{|c|}{$\begin{array}{l}\text { No. of people that shared } \\
\text { needles in the last week }\end{array}$} \\
\hline $1-10$ & 24.5 & 1.44 & $0.68-3.08$ & 57.1 & 1.29 & $0.55-2.99$ \\
\hline None & 16.9 & & & 44.4 & & \\
\hline \multicolumn{7}{|c|}{ Duration of drug injection } \\
\hline $7+$ years & 33.3 & 3.50 & $1.66-7.35$ & 65.0 & 8.06 & $1.80-35.71$ \\
\hline $0-6$ years & 12.5 & & & 18.8 & & \\
\hline \multicolumn{7}{|c|}{ Vaginal sex in the last month } \\
\hline Yes & 16.5 & 0.40 & $0.19-0.81$ & 48.4 & 1.56 & $0.31-7.81$ \\
\hline No & 33.3 & & & 37.5 & & \\
\hline \multicolumn{7}{|l|}{ HIV-1 infection } \\
\hline Yes & 39.7 & 7.52 & $3.42-16.39$ & 51.7 & 2.50 & $0.54-11.5$ \\
\hline No & 8.1 & & & 30.0 & & \\
\hline \multicolumn{7}{|l|}{ Syphilis } \\
\hline No & 13.6 & 5.00 & $2.01-12.04$ & 25.0 & 4.00 & \\
\hline
\end{tabular}

$a$ : human T cell lymphotropic virus type I; $b$ : injecting drug users; $c$ : odds ratio; $d$ : confidence interval. 

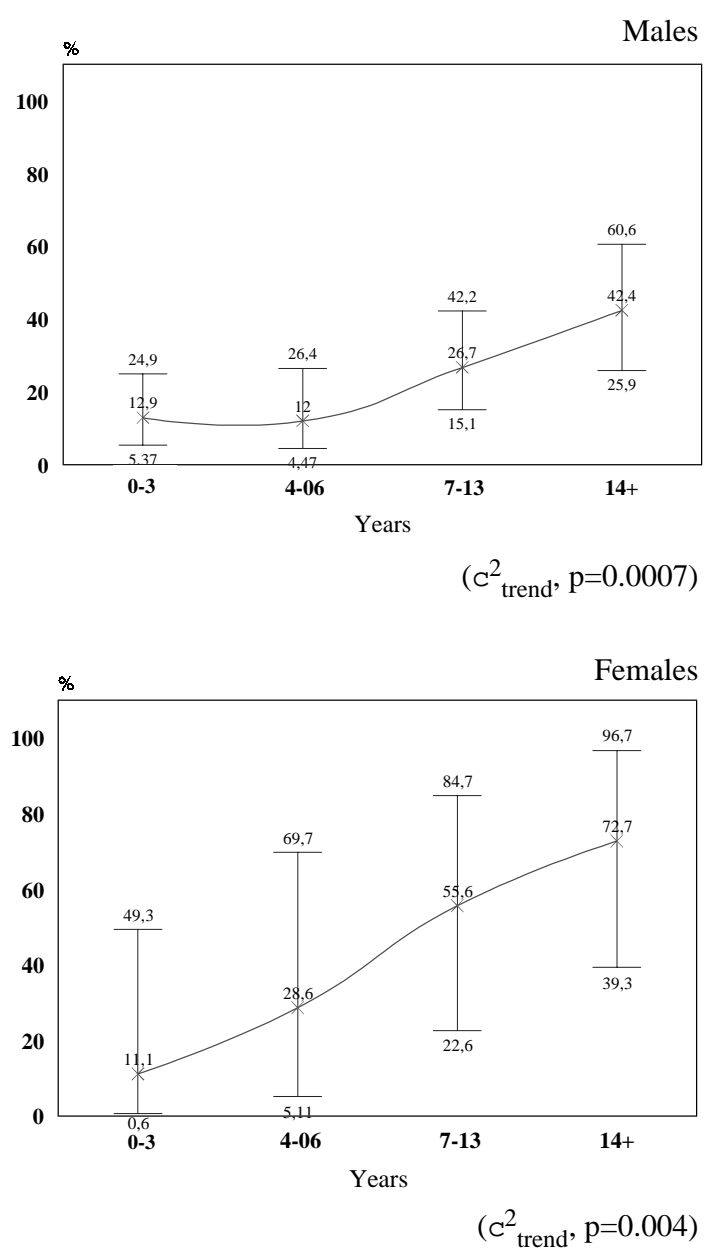

Seroprevalence of HTLV-I infection among males and females injecting drug users, by duration of injecting of drug use. Projeto Brasil-Salvador, Bahia, 1994-1996. correlate of HTLV-I infection for women (OR, 5.95; 95\% CI, 1.01-35.19). Also, the association between vaginal sex in the last month and syphilis with HTLV-I was positive (estimated ORs around 4.00), but not statistically significant. On the other hand, duration of injecting drug use (OR, $2.49 ; 95 \%$ CI, 1.02-6.03), HIV-1 infection (OR, 4.39; 95\% $\mathrm{CI}, 1.71-11.25)$ and syphilis (OR, 2.66; 95\% CI, 1.05-6.79) remained statistically significantly associated with HTLV-I infection among males. Vaginal sex in the last month had an estimated OR below the null value, but not statistically significant.

Age at enrollment in the study was strongly correlated (60\%) with duration of IDU. Age when added to the logistic regression model did not appreciably change the ORs between various risk behaviors and HTLV-I and was therefore not included.

\section{DISCUSSION}

Most studies of IDU have been carried out in clinical settings where gen-eralizability of results to other groups is of limited ability. In order to improve the representativeness of our study, we used the snowball sampling technique, a method extensively used in studies of hidden populations.

High levels of HTLV-I, and HIV-1 infection among males and females IDUs was found in Salvador. In the United States (US), Khabbaz et al. (1990), documented seroprevalence of HTLV-I/II among IDUs in eight US cities ranging from $0.4 \%$ to $17 \%$. Lee et al. (1989), reported sero-prevalence from $8.3 \%$ in Brooklyn, New York, to $24.3 \%$ in New Orleans. Furthermore, in the US, HTLV-II represents the majority of HTLV infections among

TABLE II

Logistic regression analysis for the association of HTLV-1 ${ }^{a}$ infection with selected variables among males and females IDUs ${ }^{b}$. Projeto Brasil-Salvador, Bahia, 1994-1996

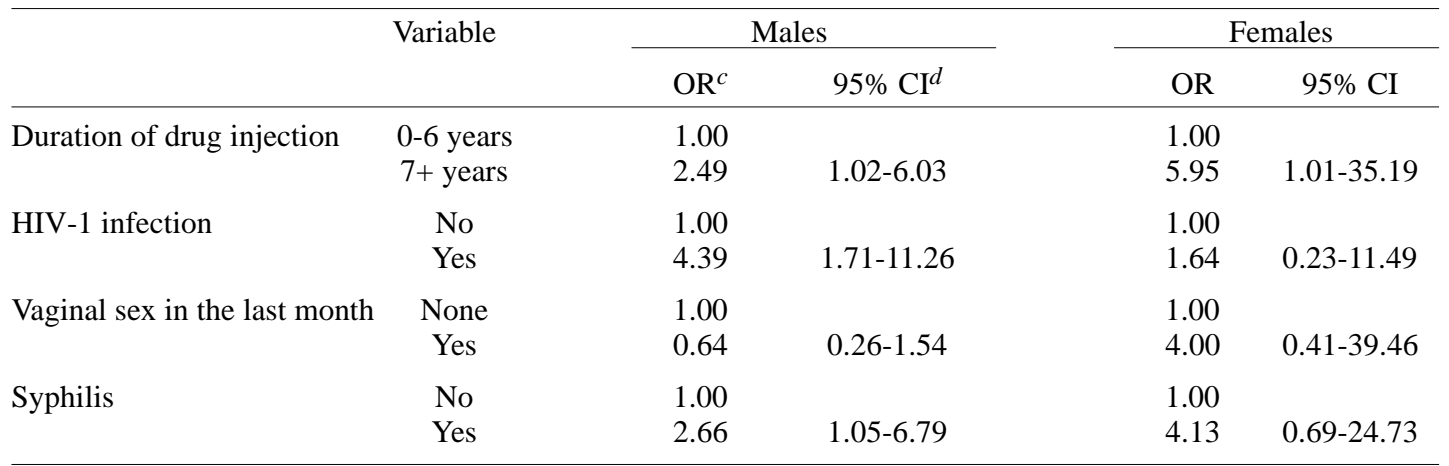

$a$ : human T cell lymphotropic virus type I; $b$ : injecting drug users; $c$ : odds ratio; $d$ : confidence interval. 
this group whereas our data demonstrated a prevalence of HTLV-I higher than HTLV-II suggesting an endemicity of HTLV-1 in this area of Brazil (Dourado et al. 1998).

Incidence data have shown that in addition to injecting drug use activities, sexual behavior also plays a role in increasing the risk for HIV-1 infection. Futhermore, women may have a higher risk of acquiring HIV by means of sexual behavior than men (Nicolosi et al. 1992). These observed features of HIV-1 transmission are probably similar for acquiring HTLV-I infection among males and females. It has been hypothesized that HTLV is transmitted more efficiently from males to females during sexual intercouse which would in part explain the observed excess of prevalence among women relative to men. In Japan, a study on HTLV infection among couples, estimated a transmission efficiency of $60.8 \%$ from males to females compared to $0.3 \%$ from females to males (Kajiyama et al. 1986).

In our study, it is possible that sexual intercourse in addition to drug use activities is playing a more important role in HTLV-I infection among women than in men. Evidence to support this hypothesis are the observations that the seroprevalence of HTLV-I infection was two times higher for women than for men; women had higher rates of syphilis (almost three times) than men and vaginal sex in the previous month was reported more frequently by women. The association of vaginal sex with HTLV-I infection did not reach statistical significant levels but the estimated OR was in the direction of a positive association. Among males the OR was in the other direction but also not statistically significant.

Other studies with greater sample sizes are needed to investigate further the role of sexual behavior as a risk factor to HTLV-I infection among male and female IDUs.

\section{ACKNOWLEDGMENTS}

To the participation of the study subjects, to the assistance with data collection of Jane Montes, Monica Coutinho and Arlene Alves, to Noilson Gonçalves technical assistance with the assays.

\section{REFERENCES}

Andrade TM, Dourado I, Galvão-Castro B 1998. Associations among HTLV-I, HTLV-II and HIV in injecting drug users in Salvador, Brazil. J Acquir Immune Defic Syndr Hum Retrov 18: 186-187.

Araujo CA, Casseb JSR, Neitzert E, Souza MLX, Mammano F, Del Mistro A, Chieco-Bianchi L 1994. HTLV-I and HTLV-II infections among HIV-1 seropositive patients in São Paulo, Brazil. Eur J Epidemiol 10: 165-171.

Bellei NCJ, Granato CFH, Tomyana H, Castelo A, Ferreira O 1996. HTLV infection in a group of prosti- tutes and their male sexual clients in Brazil: seroprevalence and risk factors. Trans $R$ Soc Trop Med Hyg 90: 122-125.

Biernack P, Walford D 1981. Snowball sampling: Problems and techniques of chain referral sampling. Sociol Methods Research 2: 141-63.

Briggs NC, Battjes RJ, Cantor KP, Blattner WA, Yellin FM, Wilson S, Ritz LA, Weiss SH,Goedert JJ 1995. Seroprevalence of Human T cell lymphotropic virus types II infection, with and without human immunodeficiency virus type 1 coinfection, among US intravenous drug users. J Infect Dis 172: 51-58.

CDC 1990. Human T- Lymphotropic virus type-I screening in volunteer blood donors - US, 1989. Morb Mortal Wkly Rep 39: 915-921.

de Carvalho HB, Mesquita F, Massad E, Bueno RC, Lopes GT, Ruiz MA, Burattini MN 1996. HIV and infections of similar transmission patterns in drug injectors community of Santos, Brazil. J Acquir Immune Defic Syndr Hum Retrov 12: 84-92.

Des Jarlais DC, Friedman P, Hagan H, Friedman SR 1996. The protective efffect of AIDS-related behavioral change among injection drug users: a crossnational study. Am J Public Health 86: 1780-1785.

Dourado I, Andrade T, Galvão-Castro B 1998. Human $\mathrm{T}$ cell Lymphotropic Virus Type 1 (HTLV- I) in Northeast Brazil: Differences for male and female injecting drug users. J Acquir Immune Defic Syndr Hum Retrov (in press).

Feigal E 1991. Human T cell lymphotropic virus types I and II in intravenous drug users in San Francisco: risk factors associated with seropositivity. $J$ Infect Dis 164: 36-42.

Ferreira Jr OC, Vaz RC, Carvalho MB, Guerra C, Fabron AL, Rosemblit J, Hamerschlak N 1994. Human Tlymphotropic virus type I and type II infections and correlation with risk factors in blood donors from São Paulo, Brazil. Transfusion 35: 1-6.

Fleiss JL 1981. Statistical Methods for Rates and Proportions, John Wiley and Sons, New York, 321 pp.

Gabbai AA, Bordin JO, Vieira-Filho JBP, Kuroda A, Oliveira ASB, Cruz MV, Ribeiro AAF, Delaney SR, Henrad DR, Rosario J, Roman GC 1993. Selectivity of human T-lymphotropic virus type- I (HTLVI) and HTLV-II infection among different populations in Brazil. Am J Trop Med Hyg 49: 664-671.

Galvão-Castro B, Loures L, Rodrigues L, Sereno A, Ferreira Jr OC, Franco LGP, Muller M, Sampaio DA, Santana A, Passos LM, Proietti F 1997. Distribution of Human T-cell Lymphotropic Virus type I among blood donors: a nationwide Brazilian study. Transfusion 37: 42.

Hesran JY Le, Delaporte E, Gaudebout C, Trebuck A, Schrijvers D, Josse R, Peeters M, Cheringou H, Dupont A, Larouze B 1994. Demographic factors associated with HTLV-1 infection in a Gabonese community. Int J Epidemiol 23: 812-817.

HTLV European Research Network 1996. The sero-epidemiology of human T-cell leukaemia/lymphoma viruses in Europe. J Acquir Immune Defic Syndr Hum Retrov 12: 1-10. 
Ishak R, Harrington Jr WJ, Azevedo VN, Eiraku N, Ishak MOG, Guerreiro JF, Santos SB, Kubo T, Monken C, Alexander S, Hall WW 1995. Identification of human $\mathrm{T}$ cell lymphotropic virus type IIa infection in the Kayapo, an indigenous population of Brazil. AIDS Res Hum Retrov 11: 813821.

Kajiyama W, Kashiwagi S, Ikematsu H, Hayashi J Nomura H, Okochi K 1986. Intra-familial transmission of adult T-cell leukemia virus. J Infect Dis 154: 851-857.

Khabbaz RF, Onorato IM, Cannon RO, Hartley TM, Roberts B, Hosein B, Kaplan JE 1990. Seroprevalence of HTLV-I and HTLV-II among intravenous drug users and persons in clinics for sexually transmitted diseases. N Engl J Med 326: 375-80.

Lee HH, Weiss SH, Brown LS, Mildvan D, Shorty V, Saravolatz L, Chu A, Ginzburg HM, Markowitz N, Des Jarlais DC, Blattner WA, Allain JP 1990. Patterns of HIV-1 and HTLV-I/II in intravenous drug abusers from the Middle Atlantic and Central Regions of the USA. J Infect Dis 162: 347-352.

Lee H, Swanson P, Shorty VS, Zack JA, Rosenblatt JD, Chen IS 1989. High rate of HTLV-II infection in seropositive intravenous drug users in New Orleans. Science 244: 471-475.

Lopes CS, Rodrigues LC, Sichieri R 1996. The lack of selection bias in a snowball sampled case-control study on drug abuse. Int J Epidemiol 25: 1267-1270.

Merino F, Robert Guroff M, Clark J, Bundo- Bracho M, Blattner WA, Gallo RC 1984. Natural antibodies to human T-cell leukemia/lymphoma virus in health Venezuelan population. Int J Cancer 34: 501-506.

Moreira ED, Ribeiro, TT, Swanson P, Filho CS, Melo A, Brites C, Badaró R, Toedter G, Lee H, Harrington Jr W 1993. Seroepidemiology of HTLV type I/II in Northeastern Brazil. J Acquir Immune Defic Syndr 6: 959-963.

Moreno-Carvalho OA, Santos JI, Di Gredico G, GalvãoCastro B 1992. Evidence of preferential female prevalence of HTLV-I associated tropical spastic paraparesis in Bahia-Brazil. Arq Neuro-Psiquiatria 50: $183-188$.
Nicolosi A, Leite MLC, Musicco M, Molinari S, Lazarrin A 1992. Parental and sexual transmission of human immunodeficiency virus in intravenous drug users: a study of seroconversion. Am J Epidemiol 135: 225233.

Poiesz BJ, Ruscetti FW, Gazdar AF, Bunn PA, Minna JD, Gallo RC 1980. Detection and isolation of type$\mathrm{C}$ retrovirus particles from fresh and cultured lymphocytes of a patient with cutaneos T-cell lymphoma. Proc Nat Acad Sci 77: 7415-7419.

Poiesz BJ, Ruscetti FW, Reitz MS, Kalyanaraman VS, Gallo RC 1981. Isolation of a new type $C$ retrovirus (HTLV) in primary uncultured cells of a patient with Sezary T-cell leukemia. Nature 294: 268-271.

Pombo de Oliveira MS, Matutes E, Famadas LC, Schulz TF, Calabro ML, Nucci M, Andrada-Serpa MJ, Tedder RS, Weiss RA, Catovsky D 1990. Adult Tcell leukemia/lymphoma in Brazil and its relation to HTLV-I. Lancet 1: 45-48.

SAS Institute Inc 1995. SAS Proprietary Software Release 6.11. Licensed to the University of North Carolina at Chapel Hill. Cary, NC.

Stimson GV 1995. The health and social cost of drug injecting: the challenge to developing countries. Presented at the sixty international conference on the reduction of drug-related harm, Florence.

Taylor GP 1996. The epidemiology of HTLV-I in Europe. J Acquir Immune Defic Syndr Hum Retrov 13: S8-S14.

Tedder RS, Shanson DC, Jeffries DJ, Cheingsong-Popov R, Clapham P, Dalgleish A, Nagy K, Weiss RA 1984. Low prevalence in the UK of HTLV-I and HTLV-II in subjects with AIDS, with extended lymphoadenopathy, and at risk of AIDS. Lancet 2: 125-128.

Vasquez P, Sanchez G, Volante C, Vera L, Ramirez E, Soto G, Lee H 1991. Human T-lymphotropic virus I: new risk for Chilean population. Blood 78: 850.

WHO-World Health Organization 1993. WHO collaborative study group on drug abuse: an international comparative study of HIV prevalence and risk behavior among drug injectors in 13 cities. Bull Narc 45: 19-46. 